\title{
Suicide attempts in a emergency hospital
}

\author{
Perfil de tentativas de suicídio em um hospital de emergência \\ Verônica de Medeiros Alves', Amanda Mirlla Santos da Silva², Ana Paula Nogueira de Magalhães³, Tiago \\ Gomes de Andrade 4 , Ana Cristina Mancussi e Faro ${ }^{5}$, Antonio E. Nardi ${ }^{6}$
}

\begin{abstract}
This study aimed to characterize the profiles of suicide attempts that were attended to in the Hospital of Alagoas in the year 2010 . Four hundred sixty-one charts and service bulletins were analyzed. Patients attempting suicide were predominately female. There were significant difference for suicide attempts (SAs) among men and women in the age of 10 to 19 years and 60 to 69 years. Women have tried more suicide aged between 10 and 19 years and men between 60 and 69 years. The ingestion of drugs was the most frequent method for women; and poisoning, use of sharp objects and hanging for men. The results of this study may contribute to elaboration, planning and implementation of preventive measures to reduce cases of SAs.
\end{abstract}

Keywords: suicide, attempted, suicide, emergency service, hospital, epidemiology.

\section{RESUMO}

Este estudo teve como objetivo caracterizar o perfil das tentativas de suicídio (TS) que foram atendidos num Hospital de Alagoas, no ano de 2010. Quatrocentos e sessenta e um boletins foram analisados. Houve diferença significativa para as tentativas de suicídio entre homens e mulheres nas faixas etárias de 10 a 19 anos e de 60 a 69 anos. As mulheres cometem mais suicídio na faixa etária entre 10 e 19 anos e os homens entre 60 e 69 anos. A ingestão de drogas foi o método mais frequente para as mulheres; o envenenamento, uso de objetos pontiagudos e enforcamento para homens. Os resultados deste estudo podem contribuir para a elaboração, planejamento e implementação de medidas preventivas em casos de TS.

Palavras-chave: tentativa de suicídio, suicídio, serviço hospitalar de emergência, epidemiologia.

The most important baseline predictors of suicide attempts (SAs) are baseline severity, the number of previous hospitalizations and the length of the current episode of depression $^{1}$. The probability of having two or more SAs over the past year increased with the severity of substance use and violent behavior across attempter subtypes. A previous study indicates that the treatment of depressive symptoms in teen attempters remains an important goal ${ }^{2}$.

Suicidal and nonsuicidal self-harm are both significant risks for depressed adolescents treated in the clinic. The presence of family dysfunction, high levels of suicidality and recent self-harm (suicidal or nonsuicidal) should alert us to a high risk for future SA. The presence of recent nonsuicidal self-injury is by far the strongest predictor of future nonsuicidal self-injury ${ }^{3}$.

A previous study has shown that, regardless of gender, the risk factors that are significantly associated with increased odds of SA include suicidal ideation, depressive symptoms, having a friend with a past history of attempted or completed suicide, and having a family member with a history of

\footnotetext{
${ }^{1}$ Master in Health Sciences at Instituto de Ciências Biológicas, Universidade Federal de Alagoas, Arapiraca AL, Brazil; Student of Postgraduated Program in Mental Health, Instituto de Psiquiatria, Universidade Federal do Rio de Janeiro, Rio de Janeiro RJ, Brazil;

${ }^{2}$ Nurse, Universidade Federal de Alagoas, Arapiraca AL, Brazil;

${ }^{3}$ Master in Public Health, Universidade Federal de Pernambuco; Student of Programa de Pós-Graduação Interunidades em Enfermagem, Escola de Enfermagem, Universidade de São Paulo. Escola de Enfermagem de Ribeirão Preto, Universidade de São Paulo, Sao Paulo SP, Brazil

${ }^{4}$ Doctor of Medical Pathophysiology at Universidade Estadual de Campinas. Universidade Federal de Alagoas, Arapiraca AL, Brazil;

${ }^{5}$ Departamento de Enfermagem Médico-Cirúrgica, Escola de Enfermagem, Universidade de São Paulo, Sao Paulo SP, Brazil;

${ }^{6}$ Postdoc in the Laboratório de Fisiologia da Respiração, Instituto de Biofísica Carlos Chagas Filho. Laboratório de Pânico e Respiração, Instituto de Psiquiatria, Universidade Federal do Rio de Janeiro. Instituto Nacional de Ciência e Tecnologia Translacional, Rio de Janeiro RJ, Brazil.

Correspondence: Verônica de Medeiros Alves, Rua Deputado Jose Lages, 1055, apto 901, Ed. Regence, Ponta Verde; 57035-330, Maceió AL, Brasil. E-mail: veronica.ufal.arapiraca@gmail.com

Conflict of Interest: There is no conflict of interest to declare.

Received 19 February 2013; Received in final form 20 September 2013; Accepted 27 September 2013.
} 
attempted suicide. Parental loss predicts the likelihood of SA after a year but not after 7 years, suggesting that the mental health consequences resulting from the death of a parent may not persist into young adulthood ${ }^{4}$.

A study of the death registration data for 83 countries identified only 20 countries that had high-quality death registration data that could be used to estimate injury mortality because the data were frequently classified using imprecise and partially specified categories. Analytical methods that can derive national estimates of injury mortality from alternative data sources are needed for countries without reliable death registration systems ${ }^{5}$.

Thus, suicide demands intersectorial actions of confrontation for damage reduction, that have multidisciplinary and transdisciplinary characteristics ${ }^{6}$. The planning and implementation of intersectorial actions is necessary to meet the profile of SA cases of the region. This objective of this study was to characterize the profile of SA cases that were attended to in the Hospital of Urgency and Emergency of interior Alagoas in the year 2010.

\section{METHOD}

This study employed a quantitative approach with descriptive and retrospective documental analysis. The study population was identified through input newsletters for patient care due to SA between January and December of 2010. All charts and service bulletins suicide attempts made in 2010 were analyzed. Newsletters that were erased, illegible or contained indefinite diagnoses of SA during the study period were excluded. Data collection was performed in the Emergency Unit by Dr. Daniel Houly, Brazil/Alagoas/Arapiraca from January to March of 2012. The Emergency Unit is a state public service that provides urgent inpatient treatment.

To extract information concerning the study sample, we used a form that included the following information: date and hour of treatment in hospital, age, sex, reason for treatment in hospital, municipality of origin, use of alcohol/drugs, use of prescriptions, presence of psychological assessments, presence of mental disorder (identified by the patient or relatives report) and methods used in the suicide attempts.

Data analysis was performed with the EPI INFO 2000 statistical program and is organized and presented in the form of a table and graphics to aid discussion of the results. The $x^{2}$ statistical test was used. Data analysis employed odds ratios with $95 \%$ confidence intervals with confidence limits, and a significance level of $\mathrm{p}<0.05$ was used to determine significance.

This study was approved by the Ethics and Research Committee of the Federal University of Alagoas/Brazil under Protocol no. 014804/ 2011-06 in December 20, 2011.

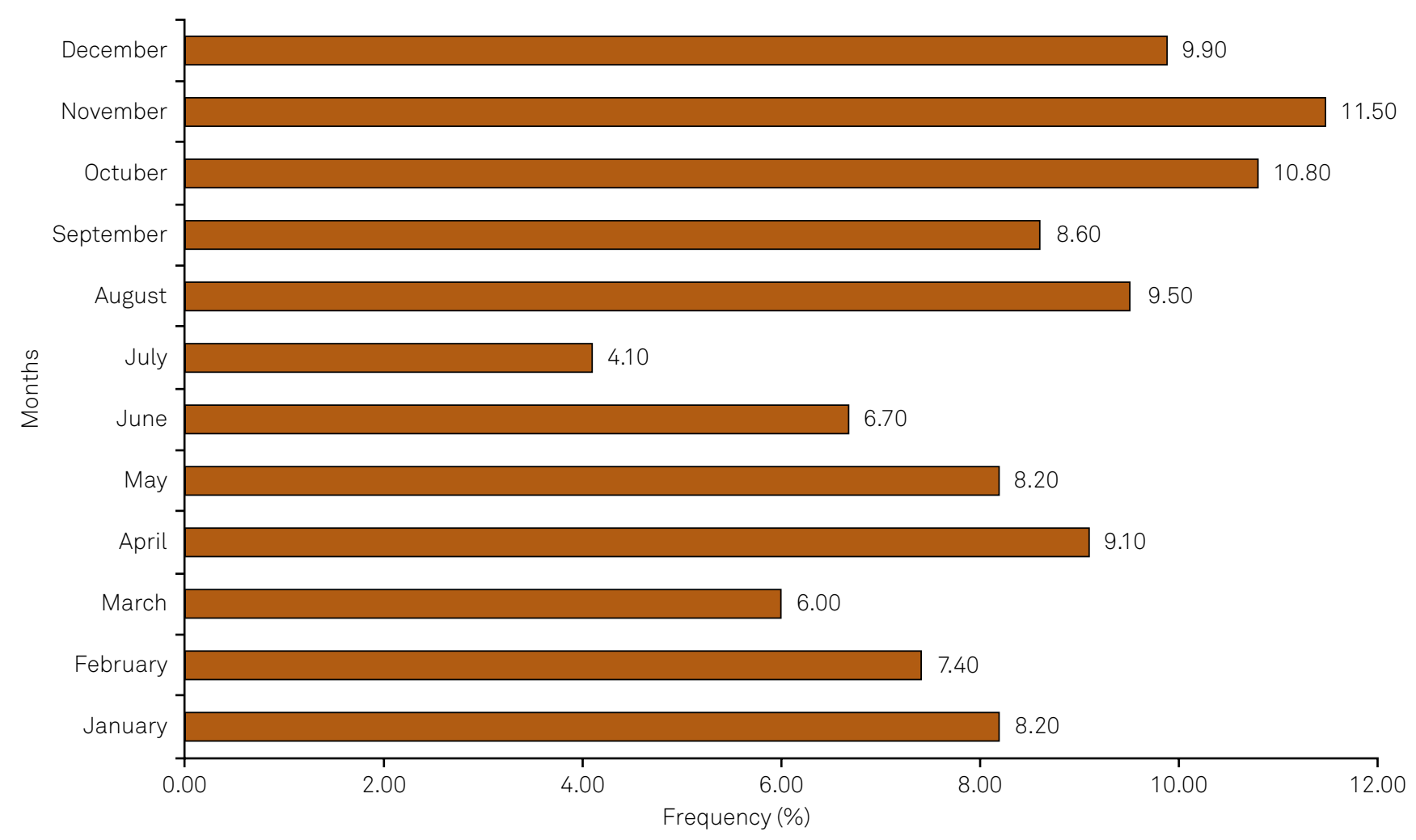

Figure. Percentage distribution by months of the year relative to cases of suicide attempt, attended in a hospital of urgency and emergency of Alagoas, Brazil, in 2010. 


\section{RESULTS}

Four hundred sixty-one cases of SA were analyzed, and there were an average of 38,4 monthly hospital visits due to SA. November was the month of with the most occurrences (53-11,5\%) hospital visits due to SA, and July had the lowest occurrence (19-4.1\%) (Figure).

SAs occurred most frequently between $12 \mathrm{~h} 00$ and $17 \mathrm{~h} 59$ hours (177-38.4\%). The interval with the least frequent occurrence of cases (46-9.9\%) was between 00h00 and 05h59 hours. Eighty-five cases occurred between 6 h00 and 11h59 (18.4\%), and $153(33.2 \%)$ cases occurred between $18 \mathrm{~h} 00$ and $23 \mathrm{~h} 59$.

We observed a predominance of SAs in females (307-66.6\%) relative to males (154-33.4\%). Comparison of the age ranges and the sexes revealed that the majority of women that tried suicide were younger than the men that did so. One hundred twenty (26\%) of the cases of SA attended to were in the age range of 10-19 years old, 178 (38.6\%) were between 20-29 years old, and 83 (18\%) were between 30-39 years old (Table 1 ). We found a statistically significant difference ( $\mathrm{p}=0.00069)$ between women and men in the age range of 10 to 19 years old; women in this age range had a 2.31 fold $(1.38<\mathrm{OR}<3.90)$ greater chance of SA than men in the same age range. The age range of 20 to 29 years old stands out as the age range with the highest occurrence of cases in both sexes (Table 1) ( $\mathrm{p}=0.3574)$. No cases of SA were found in individuals 75 years or older. In the age range of 60 to 69 years old, men had an 8.36 fold $\left(1.62<\mathrm{OR}<57.69^{*}\right)$ greater chance of SA than women in the same age range $\left({ }^{*}\right.$ Fisher test, $p=0.0031$ ). There were two cases, one in each gender, of SA in 10-year-old children.

Among the $461 \mathrm{SA}$ cases treated in Emergency Unit Dr. Daniel Houly, 220 (47.7\%) cases were from Arapiraca. Arapiraca is the second most populous city in the State of Alagoas, Brazil and has a population of 214.006 inhabitants. The 241 (52.3\%) remaining cases were referred to SA of resident people in several surrounding cities.

Women were observed to ingest medications with greater frequency (279-58.7\%) (Table 2), and this was the method most frequently used by women (225-71.2\%). A statistically significant difference $(\mathrm{p}=0.0000)$ was found in the ingestion of medications as an SA method; women had a 4.81 fold $(3.13<\mathrm{OR}<7.39)$ greater chance of using this method. The utilization of the intentional poisoning (124-26.1\%) occurred with the greatest in men (63-39.6\%) (Table 2). A statistically significant difference ( $\mathrm{p}=0.0000)$ was found in the use of poisoning in SAs; men had a 2.74 fold $(1.76<\mathrm{OR}<4.28)$ greater chance of using this method.

The most violent means of SAs, such as biting objects (25-5.3\%), hanging (7-1.5\%) and firearms (3-0.6\%), were methods that were employed preferentially by males

Table 1. Distribution of suicide attempts according to age range and gender, in the hospital of Alagoas, Brazil (urgent and emergency care), 2010.

\begin{tabular}{|c|c|c|c|c|c|c|c|}
\hline \multirow{2}{*}{ Age (years) } & \multicolumn{2}{|c|}{ Female } & \multicolumn{2}{|c|}{ Male } & \multirow{2}{*}{$p$} & \multicolumn{2}{|c|}{ Total } \\
\hline & $\mathrm{N}^{0}$ & $\%$ & $\mathrm{~N}^{\circ}$ & $\%$ & & $\mathrm{~N}^{\circ}$ & $\%$ \\
\hline 10-19 & 95 & 30.9 & 25 & 16.2 & 0.00069 & 120 & 26 \\
\hline $20-29$ & 114 & 37.1 & 64 & 41.6 & 0.3574 & 178 & 38.6 \\
\hline 30-39 & 50 & 16.3 & 33 & 21.4 & 0.1753 & 83 & 18 \\
\hline $40-49$ & 34 & 11.1 & 19 & 12.3 & 0.6885 & 53 & 11.5 \\
\hline $50-59$ & 11 & 3.6 & 5 & 3.3 & 0.8524 & 16 & 3.5 \\
\hline $60-69$ & 2 & 0.7 & 8 & 5.2 & 0.0031 & 10 & 2.2 \\
\hline Ignored & 1 & 0.3 & - & - & - & 1 & 0.2 \\
\hline Total & 307 & 100 & 154 & 100 & - & 461 & 100 \\
\hline
\end{tabular}

Table 2. Distribution of methods used in suicide attempts, in the hospital of Alagoas, Brazil (urgent and emergency care), 2010.

\begin{tabular}{|c|c|c|c|c|c|c|c|}
\hline \multirow{2}{*}{ Methods to Attempt } & \multicolumn{2}{|c|}{ Female } & \multicolumn{2}{|c|}{ Male } & \multirow{2}{*}{$\mathrm{p}$} & \multicolumn{2}{|c|}{ Total } \\
\hline & $\mathrm{N}^{\circ}$ & $\%$ & $\mathrm{~N}^{\circ}$ & $\%$ & & $\mathrm{~N}^{\circ}$ & $\%$ \\
\hline Ingestion of medication & 225 & 71.2 & 54 & 34 & 0.0000 & 279 & 58.7 \\
\hline Poisoning & 61 & 19.3 & 63 & 39.6 & 0.0000 & 124 & 26.1 \\
\hline Ingestion of cleaning products & 14 & 4.4 & 12 & 7.5 & 0.1588 & 26 & 5.5 \\
\hline Ingestion of others chemical products & 3 & 1 & 4 & 2.5 & 0.1812 & 7 & 1.5 \\
\hline Cutting objects & 8 & 2.5 & 17 & 10.7 & 0.00017 & 25 & 5.3 \\
\hline Firearms & 0 & 0.0 & 3 & 1.9 & - & 3 & 0.6 \\
\hline Hanging & 2 & 0.6 & 5 & 3.1 & 0.03204 & 7 & 1.5 \\
\hline Precipitation from a great height & 2 & 0.6 & 1 & 0.6 & 0.996 & 3 & 0.6 \\
\hline Others & 1 & 0.3 & 0 & 0.0 & - & 1 & 0.2 \\
\hline Total & 316 & 100 & 159 & 100 & - & 475 & 100 \\
\hline
\end{tabular}


(Table 2). No woman made use of a firearm in a SA. A statistically significant difference $(p=0.00017)$ in the use of biting objects as a means of SA was found; men had a 4.61 fold $(1.83<\mathrm{OR}<11.95)$ greater chance of using this method. Regarding the use of hanging, men $(5-3,1 \%)$ were more likely to use this method than women (2-0.6\%) (Table 2).

Among the cases of SA, $423(90.4 \%)$ people had a main natural lesion of intoxication. This type of lesion was followed by cuts (23-5\%), perforating wounds (5-1.1\%), asphyxia (4-0.9\%), head trauma (3-0.6\%), fractures (2-0.4\%), polytraumas $(2-0.4 \%)$, contusions $(1-0.2 \%)$, other lesions $(3-0.6 \%)$ and unreported lesions (2-0.4\%).

Among the cases of SAs by poisoning (124-26.1\%) in which the toxic agent was specified, 31 (24.2\%) were intoxicated with aldicarb. The use of a poison that is used on tobacco plantations (12-9.3\%) was also a means of SA in the population of this study.

Multiple organs (423-90\%), the upper limbs (16-3.4\%) and the neck (10-2.1\%) were the regions of the body with the most damage resulting from SAs. Following these regions were the head/face (8-1.7\%), lower limbs (8-1.7\%), abdomen/hip (2-0.4\%), thorax/dorsum (1-0.2\%) and unreported lesions (2-0.4\%).

Among the women, 17 (5.5\%) were identified as expectant mothers. Of these, seven $(41.2 \%)$ were in the first trimester of gestation, one (5.9\%) was in the second, and one (5.9\%) was in the third. This information was not available in eight $(47 \%)$ cases.

Forty-three (9.3\%) cases of SA occurred under the influence of alcohol. The frequency of the use of alcohol was higher among men (24-55.8\%) than women (19-44.2\%). A statistically significant difference $(\mathrm{p}=0.00107)$ between SA and consumption of alcohol was found; men had a 2.8 fold $(1.42<\mathrm{OR}<5.54)$ greater chance of consuming alcohol and attempting suicide.

Among the 461 newsletters analyzed, only 15(3.3\%) registers reported previous SAs, and only 42 (9.1\%) registers reported the presence of related mental disorders. The type of disorder was reported in only eight cases, and records of the use of psychoactive medications were present for only 26 (5.6\%) cases.

Regarding developments of cases, 326 (70.7\%) obtained medical discharge, 73 (15.8\%) were routed to other services, and followed after discharge to until they failed to appear (7-1.5\%), obtained a waiver (1-0.2\%), were ignored (37-8\%) or died (17-3.7\%). The routed services included Psychosocial Care Centers (53-72.6\%), ambulatory hospitals (3-4.1\%), psychiatric hospitals (3-4.1\%) and others (14-19.1\%). Only 112 (24.3\%) patients were submitted to a psychological evaluation, and $340(73.7 \%)$ did not receive this type of evaluation.

Death was more frequent in males (13-76.5\%) than females (4-23.5\%) ( $p=0.00012)$. Men had a 6.98 fold $(20.7<\mathrm{OR}<25.86)$ greater chance of death during an attempted suicide than women (Table 3). Poisoning was the main cause of death in both sexes (11-64.7\%), followed by hanging (3-17.6\%) and firearms (2-11.8\%) (Table 3). The highest incidence of death occurred in the age range of 20 to 39 years old (9-52.8\%; seven males and two females). The number of cases diminished among males at 40 years old and grew between ages of 60 to 69 years old (3-17.6\%).

\section{DISCUSSION}

Suicide attempts are violent self-inflicted events that bring serious repercussions to both the attempter and the family and friends. Discussions related to this theme are still considered taboo due to the fear that discussion may stimulate the act. It is known that speaking about suicide is one of the best methods of preventing it. Thus, research in this area is of extreme relevance to eliminate this stigma.

Epidemiological studies of suicide attempts are not common in Brazil; thus little is known about the prevalence and profiles of suicide. A study that traced the profile of 160 cases of SA that were attended to in a general hospital of Rio de Janeiro identified September as the month with the highest occurrence of the SA (20 cases), while March had the lowest occurrence $(7 \text { cases })^{7}$. The present study found the months of November and July to have the highest and lowest frequencies of suicide attempts, respectively.

Studies of cases of SA that were attended to in urgency and emergency units of Brazilian municipalities have shown prevalences in females (300-58\%) that are higher than those of males $(214-41 \%)^{8,9}$. This is similar to the current study by presenting similar sample and predominance of suicide attempts in females.

This study examined the records of three cases of SA in children. National data suggest that suicide is practically

Table 3. Distribution of deaths following suicide attempts, in the hospital of Alagoas, Brazil (urgent and emergency care), 2010.

\begin{tabular}{|c|c|c|c|c|c|c|c|}
\hline \multirow{2}{*}{ Mode of death } & \multicolumn{2}{|c|}{ Female } & \multicolumn{2}{|c|}{ Male } & \multirow{2}{*}{$\mathrm{p}$} & \multicolumn{2}{|c|}{ Total } \\
\hline & $\mathrm{N}^{\circ}$ & $\%$ & $\mathrm{~N}^{\circ}$ & $\%$ & & $\mathrm{~N}^{\circ}$ & $\%$ \\
\hline Poisoning & 3 & 27.3 & 8 & 72.7 & 0.555 & 11 & 64.7 \\
\hline Hanging & 1 & 33.3 & 2 & 66.7 & 0.579 & 3 & 17.6 \\
\hline Firearm & 0 & 0.0 & 2 & 100 & - & 2 & 11.8 \\
\hline Other substance & 0 & 0.0 & 1 & 100 & - & 1 & 5.9 \\
\hline Total & 4 & 23.5 & 13 & 76.5 & 0.00012 & 17 & 100 \\
\hline
\end{tabular}


non-existent until the age of 10 years old. However, starting at this age the SA rate strongly increases and reaches its maximum between 20 and 27 years old ${ }^{8}$. In Brazil in 2008, the number of deaths by suicide among 15 to 19 year old people was nearly double that of 10 to 14 year old people ${ }^{10}$.

The identification of the profile of the SA could contribute to strategic planning that would make possible the prevention of the use of certain SA methods or help to design plans of care for subjects who have used methods. Several studies have reported which are the more commonly used means of $\mathrm{SA}^{11-13}$. The ingestion of medication, hanging and the use of cutting objects in SAs must be taken into consideration in the planning of care for the studied population.

Despite the studies that show the relation of agrotoxins and suicide attempts, it is not yet known why this relationship exists ${ }^{14,15}$. In the actual study, the authors perceive the necessity of investigating the influence of agrotoxins on SAs in view of the relevant of the use of this substance in SAs. Exposure to pesticides has been linked to increases in SAs in Brazilian workers ${ }^{15}$.

SAs of pregnant women raise the suspicion of the presence of a mental disorder. Hormonal changes may also be factors affecting the predisposing to SAs in the pregnant. Maternal suicide is associated with an increased risk of suicide-attempt hospitalization in the offspring that goes beyond the risk associated with maternal accidental death ${ }^{16}$.

A study showed a relation of alcohol consumption and a greater frequency of SAs that is consonant with results of this research. A study that interviewed 4,352 individuals identified 423 (9.7\%) people that did use alcoholic drinks. Among those who used alcohol drinks, 34 (8\%) had histories of SAs, and SAs were most common in males (26-76.5\%) in the age range of 18 to 35 years old $(18-53 \%)^{17}$.

Several motives can lead a subject to attempt suicide, but the presence of a mental disorder is one of the predictive factors ${ }^{18,19}$. The record in relation the presence of a mental disorder and the use and type of psychotropic medications used can underestimate the reality of the intents; indeed the literature indicates that the presence of a mental disorder is one of the main risk factors for suicidal behavior ${ }^{20}$.

The main limitation of this study was the sub-enrollment of presence of mental disorders. It was impossible for the realization of the association of mental disorders with suicide attempts. Another limitation was the difficulty to identify suicide attempts, because many of hospital's outpatient clinic attendances studied may have been suicide attempts (e.g. accidents).

In this study, the most frequently used method of SA among those who died was poisoning, followed by hanging and the use of a firearm. This finding differs from that of a study performed in Amurel (southern Santa Catarina) that indicated hanging was the most-used method to commit the suicide (67-68.4\%), followed by use of a firearm (12-12.2\%), exogenous intoxication (8-8.2\%) and drowning $(6-6.1 \%)^{21}$.

In contrast to this study, which found a higher frequency of deaths between the ages of 20 to 39 years old, another study that was performed between 1980 and 2005 and examined cases of death by suicide in the extreme West of Santa Catarina found that the majority of the deaths occurred in the age range of 20 to 49 years old. This study found that the number of deaths was lowest $(4 / 100,000)$ in the age range between 10 to 19 years old and highest $(60 / 100,000)$ in individuals over 60 years old ${ }^{22}$.

The results of this study support those reported in the literature. The prevalence of SA was higher in females, especially in the younger population (10 to 29 years old). Intoxication was the main method used, and medications were predominantly used by women, followed by intentional poisoning by men. Cutting objects, hanging and firearms were used by men.

The present study served as a subsidy in the planning and elaboration of new instruments and strategies of prevention. The necessity of intervention in the area of promoting health to detect and prevent new suicide behaviors both local and regional was noticed. We also emphasized the need for improvement in the quality of records available.

\section{Acknowledgements}

We thank the direction of Urgency and Emergency Hospital Dr Daniel Houly for providing the data collected in this research. We thank Sonia Mercia da Silva for their support at the beginning of the collection in this hospital.

\section{References}

\footnotetext{
1. Riedel $M$, Möller $\mathrm{H}$-J, Obermeier $\mathrm{M}$, et al. Clinical predictors of response and remission in inpatients with depressive syndromes. J Affect Disord 2011;133:137-149.

2. Pena JB, Matthieu MM, Zayas LH, Masyn KE, Caine ED. Co-occurring risk behaviors among White, Black, and Hispanic US high school adolescents with suicide attempts requiring medical attention, 1999-
}

2007: implications for future prevention initiatives. Soc Psychiatry Psychiatr Epidemiol 2012;47:29-42.

3. Wilkinson P, Kelvin R, Roberts C, Dubicka B, Goodyer I. Clinical and psychosocial predictors of suicide attempts and nonsuicidal self-injury in the adolescent depression antidepressants and psychotherapy trial (ADAPT). Am J Psychiatry 2011;168:495-501. 
4. Thompson MP, Light LS. Examining gender differences in risk factors for suicide attempts made 1 and 7 years later in a nationally representative sample. J Adolesc Health 2011;48:391-397.

5. Bhalla K, Harrison JE, Shahraz S, Fingerhut LA. Availability and quality of cause-of-death data for estimating the global burden of injuries. Bull World Health Organ 2010;88:831-838.

6. Bezerra FilhoJG, Werneck GL,Almeida RLF, Oliveira MIV, Magalhães FB. Estudo ecológico sobre os possiveis determinantes socioeconômicos, demográficos e fisiográficos do suicídio no Estado do Rio de Janeiro, Brasil, 1998-2002. Cad Saúde Pública 2012;28:833-844.

7. Werneck GL, Hasselmann MH, Phebo LB, Vieira DE, Gomes VLO. Tentativas de suicídio em um hospital geral no Rio de Janeiro, Brasil. Cad Saúde Pública 2006;22:2201-2206.

8. Sá NNB, Oliveira MGC, Mascarenhas MDM, Yokota RTC, Silva MMA, Malta DC. Atendimentos de emergência por tentativas de suicídio, Brasil, 2007. Rev Méd Minas Gerais 2010;20:145-152.

9. Lee CA, Choi SC, Jung KY, et al. Characteristics of patients who visit the emergency department with self-inflicted injury.J Korean Med Sci 2012;27:307-312.

10. Waiselfisz JJ. Mapa da violência 2011: os jovens no Brasil. - São Paulo: Instituto Sangari; Brasília, DF: Ministério da Justiça, 2011.

11. Ajdacic-Gross $V$, Weiss $M G$, Ring $M$, $t$ al. Methods of suicide: international suicide patterns derived from the WHO mortality database. Bull World Health Organ 2008;86:726-732.

12. Almeida SA, Guedes PMM, Nogueira JA, França UM, Oliveira e Silva AC. Investigação de risco para tentativa de suicídio em hospital de João Pessoa- PB. Rev Eletrôn Enfermagem 2009;1:383-389.

13. Chang S-S, Lu T-H, Sterne JAC, Eddleston M, Lin J-J, Gunnell D. The impact of pesticide suicide on the geographic distribution of suicide in Taiwan: a spatial analysis. BMC Public Health 2012;12:260.
14. Banerjee S, Chowdhury AN, Schelling E, Brahma A, Biswas MK, Weiss MG. Deliberate self-harm and suicide by pesticide ingestion in the Sundarban region, India. Trop Med Internat Health 2009;14:213-219.

15. Minayo MCS. Conceitos, teorias e tipologias de violência: a violência faz mal à saúde. In: Njaine K, Assis SG, Constantino P. (Org.). Impactos da violência na saúde. Rio de Janeiro: Fiocruz, 2010:21-42.

16. Kuramoto SJ, Stuart EA, Runeson B, Lichtenstein P, Långström Holly N, Wilcox C. Maternal or Paternal suicide and offspring's psychiatric and suicide-attempt hospitalization risk. Pediatrics 2010;1026-1032.

17. Lima DD, Azevedo RCS, Gaspar KC, Silva VF, Mauro MLF, Botega NJ. Tentativa de suicídio entre pacientes com uso nocivo de bebidas alcoólicas internados em hospital geral. J Bras Psiquiatr 2010;59:167-172.

18. Kauer-Sant'Anna MA, Frey BN, Andreazza AC, et al. Anxiety comorbidity and quality of life in bipolar disorder patients. Canad $J$ Psychiatry 2007;52:175-181.

19. Bolton JM, Robinson J. Population-attributable fractions of axis I and axis II mental disorders for suicide attempts: findings from a representative sample of the adult, noninstitutionalized US population. Am J Public Health 2010;100:2473-2480.

20. Bertolote JML, Mello-Santos C, Botega NJ. Detecção do risco de suicídio nos serviços de emergência psiquiátrica. Rev Bras Psiquiatr 2010;32(Suppl):S87-S95.

21. Viana GN, Zenkner FM, Sakae TM, Escobar BT. Prevalência de suicídio no Sul do Brasil, 2001-2005. J Bras Psiquiatr 2008;57:38-43.

22. Schmitt R, Lang MG, Quevedo J, Colombo T. Perfil epidemiológico do suicídio no extremo oeste do estado de Santa Catarina, Brasil. Rev Psiquiatr Rio Grande do Sul 2008;30:115-123. 